\title{
SPENT MUSHROOM SUBSTRATE of Pleurotus ostreatus KUMMER INCREASES BASIL BIOMASS AND ESSENTIAL OIL YIELD ${ }^{1}$
}

\author{
CRISTIANO OLIVEIRA DO CARMO ${ }^{2}$, MARCOS DE SOUZA RODRIGUES ${ }^{2}$, FRANCELI DA SILVA², TÂMARA \\ GRAZIELE MATOS IRINEU ${ }^{2}$, ANA CRISTINA FERMINO SOARES ${ }^{2 *}$
}

\begin{abstract}
Lignocellulosic residues are used to produce mushrooms, but they generate large amounts of spent mushroom substrate (SMS). The objective of this study was to evaluate they effect of SMS of Pleurotus ostreatus, combined with organic fertilization, on biomass production and essential oil yield of basil (Ocimum basilicum L.) plants. The fertilizer was formulated using combinations of organic compounds: SMS, organic compost (OC), and earthworm humus (EH). The treatments were applied using $35 \mathrm{~g}$ of the formulations, corresponding to an application of $20 \mathrm{Mg} \mathrm{ha}^{-1}$. The treatments used were: $100 \% \mathrm{OC} ; 100 \% \mathrm{EH} ; 100 \% \mathrm{SMS}$; $75 \% \mathrm{SMS}+25 \% \mathrm{OC}(\mathrm{C} 1) ; 75 \% \mathrm{SMS}+25 \% \mathrm{EH}(\mathrm{C} 2) ; 50 \% \mathrm{SMS}+50 \% \mathrm{OC}(\mathrm{C} 3) ; 50 \% \mathrm{SMS}+50 \% \mathrm{EH}(\mathrm{C} 4) ;$ $50 \% \mathrm{SMS}+25 \% \mathrm{OC}+25 \% \mathrm{EH}(\mathrm{C} 5)$, and a control with no fertilizer application (CT). Plants grown with the soil fertilizers containing SMS, single or combined with OC and EH, presented higher average plant height $(55.6$ to $62.2 \mathrm{~cm})$ and leaf area per plant $\left(696.5\right.$ to $\left.836.4 \mathrm{~cm}^{2}\right)$. The treatment $\mathrm{C} 3$ resulted in plants with higher mean dry weight $\left(10.9 \mathrm{~g} \mathrm{plant}^{-1}\right)$, and C2 resulted in the highest oil yield $\left(5.0 \mathrm{~kg} \mathrm{ha}^{-1}\right)$, representing a gain of $324.8 \%$ in oil yield when compared to the control. Thus, SMS increases biomass production and essential oil yield of basil plants.
\end{abstract}

Keywords: Ocimum basilicum. Sisal residue. Organic fertilization. Medicinal plants.

\section{SUBSTRATO PÓS-CULTIVO DE Pleurotus ostreatus Kummer AUMENTA A BIOMASSA E RENDIMENTO DE OLEO ESSENCIAL NO MANJERICÃO}

RESUMO - Resíduos lignocelulósicos são usados na produção de cogumelos, mas geram grandes quantidades de substrato pós-cultivo de cogumelo (SPC). Neste estudo avaliou-se o SPC de Pleurotus ostreatus, aliado a adubação orgânica na produção de biomassa e rendimento de óleo essencial de manjericão (Ocimum basilicum L.). As formulações das adubações foram preparadas com o SPC, composto orgânico (CO) e húmus de minhoca (HM) e suas combinações, todos com aplicação de $35 \mathrm{~g}$ no solo, equivalente a $20 \mathrm{t} \mathrm{ha}^{-1}$. Os tratamentos foram: $\mathrm{CO}=100 \% ; \mathrm{HM}=100 \% ; \mathrm{SPC}=100 \% ; \mathrm{C} 1=75 \% \mathrm{SPC}+25 \% \mathrm{CO} ; \mathrm{C} 2=75 \% \mathrm{SPC}+$ $25 \% \mathrm{HM} ; \mathrm{C} 3=50 \% \mathrm{SPC}+50 \% \mathrm{CO} ; \mathrm{C} 4=50 \% \mathrm{SPC}+50 \% \mathrm{HM} ; \mathrm{C} 5=50 \% \mathrm{SPC}+25 \% \mathrm{CO}+25 \% \mathrm{HM} \mathrm{e}$ $\mathrm{CT}=$ sem adubação. O comprimento médio e a área foliar foram superiores nas plantas cultivadas no solo contendo o SPC, individualmente ou combinado com as fontes orgânicas, com 55,6 a 62,2 cm de comprimento e 696,5 a $836,4 \mathrm{~cm}^{2}$ de área foliar por planta. O tratamento $\mathrm{C} 3$ proporcionou plantas com maior acumulo de matéria seca $\left(10,9 \mathrm{~g} \mathrm{planta}^{-1}\right)$ e o C2 proporcionou maior rendimento de óleo $\left(5,0 \mathrm{~kg} \mathrm{ha}^{-1}\right)$, com ganho de 324,8 \% no rendimento, em relação ao controle. O SPC promove um aumento significativo na biomassa e no rendimento de óleo essencial em plantas de manjericão (Ocimum basilicum).

Palavras-chave: Ocimum basilicum. Resíduo de sisal. Adubação orgânica. Plantas medicinais.

\footnotetext{
${ }^{*}$ Corresponding author

${ }^{1}$ Received for publication in $07 / 31 / 2020$; accepted in $03 / 23 / 2021$.

Paper extracted from the doctoral thesis of the first author.

${ }^{2}$ Center for Agricultural, Environmental and Biological Sciences, Universidade Federal do Recôncavo da Bahia, Cruz das Almas, BA, Brazil; cristian_oli10@yahoo.com.br - ORCID: 0000-0001-5356-8511, marcossouza1210@gmail.com - ORCID: 0000-0003-2059-3061, franceli.silva@gmail.com - ORCID: 0000-0003-4064-3062, tamara.matos@outlook.com.br - ORCID: 0000-0001-5877-3151, acsoares@ufrb.edu.br-ORDIC: 0000-0002-4014-1794.
} 


\section{INTRODUCTION}

The agroindustrial production generates, in general, large quantities of lignocellulosic residues, and most of them are discarded due to the high operating cost for their use (NASCIMENTO FILHO; FRANCO, 2015). Technologies for the use of these residues are required to avoid environmental pollution (BARH et al., 2018) and for the conservation of natural resources.

Fungi of the genus Pleurotus colonize several lignocellulolytic residues and produce mushrooms that are appreciated for their flavor, nutritional value, and medicinal properties (CARRASCOGONZÁLEZ; SERNA-SALDÍVAR; GUTIÉRREZURIBE, 2017). Mushroom species of the genus Pleurotus are the second most produced commercial edible mushrooms in the world (RAMAN et al., 2020). Pleurotus ostreatus, known as oyster mushroom, is highlighted among these species; it can be produced on several residues, such as coffee peels (NUNES et al., 2012), cotton seeds (GIRMAY et al., 2016), sawdust (VIEIRA; ANDRADE, 2016), sugarcane and maize bagasse, wheat and rice straws (SARDAR et al., 2016; KOUTROTSIOS, et al., 2017), palm oil bagasse (SILVA et al., 2020), and residues from sisal leaf decortication and processing (CARMO et al., 2021). However, the production of mushrooms generates a large amount of spent mushroom substrate (SMS) (KAPU et al., 2012). Approximately $5 \mathrm{~kg}$ of SMS are generated per kilogram of fresh mushrooms produced (PAREDES et al., 2016; CORRÊA et al., 2016); these SMS are often discarded in locations distant from the production site to avoid the proliferation of flies, insects, and diseases (MARQUES et al., 2014; LOPES et al., 2015). However, this procedure can contaminate the environment and waste natural resources.

Fungal degradation during the growth of mushrooms changes the physical, chemical, and biological characteristics of lignocellulosic residues (SHARMA; ARORA, 2015), which can be used as a soil organic fertilizer to produce seedlings (LOPES et al., 2015; NAKATSUKA et al., 2016; PAULA et al., 2017), for bioremediation of soils (GARCÍADELGADO et al., 2013; ADENIPEKUN; LAWAL, 2012), and as animal feed (WANZENBÖCK et al., 2017). However, the potential of using SMS is still little explored and has not solved the problem of accumulation of these residues (PAREDES et al., 2016).

The viability of applying SMS in horticulture, single or combined with other organic or mineral fertilizers, has been studied (LOU et al., 2017; NAKATSUKA et al., 2016; HANAFI et al., 2018). Medicinal plants, such as basil (Ocimum basilicum L.), are among horticultural plants that can benefit from the use of biofertilizers formulated with SMS and other organic sources of nutrients (HANAFI et al., 2018). Basil is a medicinal plant that produces an essential oil with several bioactive constituents and is used as an ingredient for cooking and preparation of drinks (WANNISSORN, et al., 2005; BURDUCEA et al., 2018).

The bioconversion of agroindustrial residues into mushrooms, combined with the use of SMS for agricultural production, enables the development of agroindustrial production systems that do not accumulate residues and generate products with commercial value, meeting the concepts of the bioeconomy (CUNHA ZIED et al., 2020). Thus, the objective of the present work was to evaluate the effect of SMS of Pleurotus ostreatus, combined with organic compost and earth earthworm humus, on biomass production and essential oil yield of basil plants.

\section{MATERIAL AND METHODS}

\section{Preparation of Basil (Ocimum basilicum L.) seedlings}

The experiment was conducted in a greenhouse at the Universidade Federal do Recôncavo da Bahia (UFRB), campus Cruz das Almas, Bahia, Brazil (12 39'33.7"S and $39^{\circ}$ $\left.05^{\prime} 05.9^{\prime \prime} \mathrm{W}\right)$, from April to July, 2018. In this period, the mean minimum and maximum temperatures were 24.0 and $25.3^{\circ} \mathrm{C}$ in April, 22.5 and $23.5^{\circ} \mathrm{C}$ in May, and 21.7 and $22.7{ }^{\circ} \mathrm{C}$ in June; and the mean minimum and maximum relative air humidity outside the greenhouse were $78.5 \%$ and $84.9 \%$ in April, $85.7 \%$ and $90.5 \%$ in May, and $87.0 \%$ and $91.6 \%$ in June. The basil seedlings were produced from seeds of the Alfavaca Verde variety sown in 128-cell plastic trays of $53 \mathrm{~cm}$ length and $27 \mathrm{~cm}$ width. The basil seeds were germinated and initially grown in a coconut fiber substrate in a greenhouse (Van der Hoeven) with plastic cover and $50 \%$ shade screen in the laterals, with daily irrigation by a sprinkler system for 30 days.

\section{Substrate preparation and formulation}

The spent mushroom substrate (SMS) was generated from the production of Pleurotus ostreatus mushrooms in a substrate composed of solid residues from leaf decortication of sisal plants (Agave sisalana Perrine) for fiber extraction and from industrial processing of dry sisal fibers, as described by Carmo et al., (2021). The SMS was dried in a forced air circulation oven (Solab, model SL-102) at $45^{\circ} \mathrm{C}$ until constant weight for the preparation of the 
soil fertilizer formulations. The organic compost $(\mathrm{OC})$ and earthworm humus $(\mathrm{EH})$ were produced using pruning residues of the experimental farm of the UFRB (Cruz das Almas campus), and the EH was produced using Californian earthworms (Eisenia andrei Bouché). The treatments are described in Table 1.

Table 1. Treatments consisted of biofertilizer with spent mushroom substrate of Pleurotus ostreatus (SMS), organic compost (OC), and earthworm humus $(\mathrm{EH})$, single or in combined $(\mathrm{C} 1-\mathrm{C} 5)$ formulations.

\begin{tabular}{cccc}
\hline Treatments & OC (\%) & EH (\%) & SMS (\%) \\
\hline OC & 100 & 0 & 0 \\
EH & 0 & 100 & 0 \\
SMS & 0 & 0 & 100 \\
C1 & 25 & 0 & 75 \\
C2 & 0 & 25 & 50 \\
C3 & 50 & 0 & 50 \\
C4 & 0 & 50 & 50 \\
C5 & 25 & 25 & 0 \\
CT & 0 & 0 & 0 \\
\hline
\end{tabular}

The biofertilizer was applied to the soil at a rate of $35 \mathrm{~g}$ per pot with 3.5 liters of soil, representing an application of $20 \mathrm{t} \mathrm{ha}^{-1}$, which was based on recommendations commonly used for medicinal plants (LAMEIRA; PINTO, 2008). The soil was collected from a pasture area of the UFRB (Cruz das Almas campus) and sieved with a galvanized wire mesh sieve (8 mesh; $2.79 \mathrm{~mm}$ opening). The soil was mixed with the SMS, OC, and EH formulations (Table 1) and placed in 3.6-liter plastic pots $(22 \mathrm{~cm}$ diameter and $18.1 \mathrm{~cm}$ length). Basil seedlings with $15 \mathrm{~cm}$ height were transplanted into the pots containing the soil and fertilizers, according to the treatments, and were grown in a greenhouse with an automatic sprinkler irrigation system. The chemical characteristics of $\mathrm{OC}, \mathrm{EH}$, and SMS are described in Table 2.

Table 2. Chemical characteristics of spent mushroom substrate of Pleurotus ostreatus (SMS), organic compost (OC), and earthworm humus (EH) used in soil fertilizer formulations for growth of Ocimum basilicum L plants.

\begin{tabular}{lccc}
\hline \multicolumn{1}{c}{ Characteristics } & OC & EH & SMS \\
\hline $\mathrm{pH}$ & 7.5 & 7.8 & 6.60 \\
Organic Matter (\%) & 21.98 & 36.46 & 61.17 \\
Organic Carbon (\%) & 10.79 & 18.88 & 32.61 \\
Total Nitrogen (\%) & 1.98 & 2.29 & 1.72 \\
Phosphorus (\%) & 0.59 & 1.09 & 0.77 \\
Potassium (\%) & 1.00 & 1.10 & 0.23 \\
Calcium (\%) & 3.04 & 1.56 & 10.44 \\
Magnesium (\%) & 0.71 & 0.73 & 0.51 \\
Sulfur (\%) & 0.12 & 0.03 & 0.20 \\
C to N ratio (C/N) & 5 & 8 & 19 \\
\hline
\end{tabular}

\section{Evaluated parameters}

The biometric evaluations of plants were carried out every 15 days over 60 days. Destructive evaluations were carried out every 15 days using two basil plants of each treatment, which were randomly selected from each experimental plot. Six plants were evaluated at the ending of the experiment (60 days). Plant growth was evaluated by measuring the shoot length (SL; $\mathrm{mm}$ ) with a $30 \mathrm{~cm}$ ruler, the stem diameter (SD) with a ruler, and the leaf area (LA) by using the Image J program (MARTIN et al., 2013). Two plants were removed from the pots every 15 days, and cut to separate the leaves, stems, and roots for determination of LA. These plant parts were then placed in a forced air circulation oven (Solab, model SL-102) at $45{ }^{\circ} \mathrm{C}$ until constant weight and weighed in a semi-analytical balance with precision of $0.001 \mathrm{~g}$ to obtain the leaf, stem, root, and total dry weights. The total dry weight was calculated based on the sum of root, stem, and leaf dry weights, and the harvest index (IC) was calculated by the leaf dry 
weight to total dry weight ratio.

\section{Essential oil extraction}

The basil essential oil was extracted by hydro -distillation, with four replications, at the Laboratory of Phytochemistry of the UFRB. Samples of $30 \mathrm{~g}$ of dry leaves of plants, which were collected at 60 days after transplanting of seedlings and dried at $45^{\circ} \mathrm{C}$ in a forced air circulation oven (Solab, model SL-102), were placed in a 2-liter glass flask containing enough distilled water to totally cover the plant material for the hydro-distillation process. A Clevenger device coupled to the glass flask was used. The extraction process was carried out for 2 hours from the first drop of the condensation, and the volume of the extracted oil was measured in the Clevenger column. The essential oil was extracted from the Clevenger column by using a glass pipette with capacity for 5 $\mathrm{mL}$, and it was stored in glass bottles covered with aluminum foil in a refrigerator at $4{ }^{\circ} \mathrm{C}$.

The essential oil content was calculated on moisture free basis, which represents the volume $(\mathrm{mL})$ of essential oil in relation to the dry weight, using Equation 1:

$$
\mathrm{OC}=\mathrm{VO} /[\mathrm{LB}-(\mathrm{LB} \times \mathrm{M})] * 100
$$

$\mathrm{OC}=$ oil content $(\%)$

$\mathrm{VO}=$ volume of oil extracted

$\mathrm{LB}=$ Leaf biomass

$\mathrm{LB} \times \mathrm{M}=$ Moisture content in the leaf biomass

LB- $(\mathrm{LB} \times \mathrm{M})=$ Quantity of dry biomass

The essential oil yield was calculated by multiplying the oil content by the leaf dry weight of the plants.

\section{Statistical analysis}

A completely randomized experimental design was used, with nine treatments and four replications; each experimental plot consisted of twelve plants (one plant per pot), totaling 432 pots. The data were compared by analysis of variance (ANOVA) and grouped by the Scott-Knott test at 5\% probability, using the Sisvar program (FERREIRA, 2011).

\section{RESULTS AND DISCUSSION}

The biomass production of basil plants over time, as a result of the soil fertilization with SMS single or combined with $\mathrm{OC}$ or $\mathrm{EH}$, is presented in Table 3. The growth of basil plants varied according to the treatments and evaluation time. The first evaluation, carried out at 15 days after transplanting of seedlings, showed no differences between the treatments for shoot length (SL), leaf area (LA), and total dry weight (TDW) of basil plants. The stem diameter (SD) showed significantly lower results only in the treatments C5 and CT (Table 3).

The treatments with SMS, single or combined with $\mathrm{OC}$ and $\mathrm{EH}$, showed the best results at 30 and 45 days after transplanting of seedlings, followed by the treatments with $\mathrm{OC}$ and $\mathrm{EH}$. When $\mathrm{OC}$ and $\mathrm{EH}$ were combined with SMS, they showed similar results for SL, LA, and TDW of basil plants (Table $3)$. However, plants in the treatments with $\mathrm{OC}$ and $\mathrm{EH}$, without SMS, started to present symptoms of nutritional deficiency (yellowing of leaves and reduced growth) at 30 days after seedling transplanting, whereas the treatments that included SMS showed plants with higher growth and vigor.

The treatments with SMS, single or combined with OC and EH, presented no significant differences $(p>0.05)$ in SL and LA of basil plants at 60 days after transplanting of seedlings, showing greater results than the treatments with $100 \%$ OC, $100 \% \mathrm{EH}$, and the control. The plants without soil fertilization (CT) had the lowest SD. The formulation with $50 \%$ SMS $+50 \%$ OC (C3) resulted in statistically higher TDW than the other treatments, with a mean of $10.9 \mathrm{~g}$, and an increase of $600 \%$ in biomass when compared to the plants in the control treatment.

The application of organic fertilizers increases the yield and improves the quality of agricultural products. The addition of $\mathrm{OC}$ and $\mathrm{EH}$ improves the soil chemical, physical, and biological properties by decreasing soil density, promoting root growth, increasing water retention capacity, and releasing nutrients to plants (NARDI et al., 2004). In addition to the effects on the soil structural and biological properties, the application of organic soil fertilizers is also associated with higher microbial biomass and activity (MASMOUDI et al., 2020).

The lower SL $(20.9 \mathrm{~cm})$, SD $(3.1 \mathrm{~mm}), \mathrm{LA}$ $\left(118.2 \mathrm{~cm}^{2}\right)$, and TDW $(1.1 \mathrm{~g})$ at 30 days after transplanting of basil seedlings were observed in the treatments with SMS, which may be related to a slower release of nutrients. SMS is rich in nutrients, as shown in Table 1, but many of these nutrients are not in forms available to plants and are slowly mineralized, especially nitrogen $(\mathrm{N})$, phosphorus $(\mathrm{P})$, and potassium (K) (HACKETT, 2015; LOU et al., 2015). In addition, nutrient losses by leaching are higher when using chicken manure instead of SMS, as found by Holbeck et al. (2013), who reported that the low humic acid contents in SMS delayed the nitrification of $\mathrm{NH}_{4}^{+}$. This can cause a slow and sustainable nutrient mineralization and availability to plants, decreasing $\mathrm{N}$ losses. Medicinal and aromatic plants, as well as other crops, depend on the adequate supply of nutrients for a high yield (CORRÊA et al., 2010). Basil plants have a high demand for N (LIMA et al., 2020). 
C. O. CARMO et al.

Table 3. Length, stem diameter, leaf area, and total dry weight of basil (Ocimum basilicum L.) plants at 15, 30, 45, and 60 days after transplanting of seedlings $(15 \mathrm{~cm}$ length) to 3.5 -liter pots containing soil fertilized with $35 \mathrm{~g}$ of spent mushroom substrate of Pleurotus ostreatus (SMS), organic compost (OC), and earthworm humus (EH), single or combined (C1 - C5) formulations.

\begin{tabular}{ccccccccc}
\hline Treatments & \multicolumn{9}{c}{ Length $(\mathrm{cm})$} & \multicolumn{4}{c}{ Stem diameter $(\mathrm{mm})$} \\
\hline OC & 15 & 30 & 45 & 60 & 15 & 30 & 45 & 60 \\
\hline EH & $10.35 \mathrm{a}$ & $29.08 \mathrm{~b}$ & $40.13 \mathrm{c}$ & $48.48 \mathrm{~b}$ & $2.95 \mathrm{a}$ & $4.88 \mathrm{a}$ & $5.38 \mathrm{a}$ & $6.50 \mathrm{a}$ \\
SMS & $8.04 \mathrm{a}$ & $27.13 \mathrm{~b}$ & $40.89 \mathrm{c}$ & $50.44 \mathrm{~b}$ & $3.08 \mathrm{a}$ & $5.13 \mathrm{a}$ & $5.50 \mathrm{a}$ & $6.50 \mathrm{a}$ \\
C1 & $10.50 \mathrm{a}$ & $20.91 \mathrm{c}$ & $46.68 \mathrm{~b}$ & $62.24 \mathrm{a}$ & $3.13 \mathrm{a}$ & $5.00 \mathrm{a}$ & $5.75 \mathrm{a}$ & $6.50 \mathrm{a}$ \\
C2 & $11.56 \mathrm{a}$ & $26.11 \mathrm{~b}$ & $51.34 \mathrm{a}$ & $57.09 \mathrm{a}$ & $3.25 \mathrm{a}$ & $5.00 \mathrm{a}$ & $6.00 \mathrm{a}$ & $6.13 \mathrm{a}$ \\
C3 & $9.81 \mathrm{a}$ & $30.53 \mathrm{a}$ & $49.53 \mathrm{a}$ & $60.88 \mathrm{a}$ & $3.06 \mathrm{a}$ & $4.50 \mathrm{a}$ & $5.75 \mathrm{a}$ & $5.75 \mathrm{a}$ \\
C4 & $12.48 \mathrm{a}$ & $33.61 \mathrm{a}$ & $51.08 \mathrm{a}$ & $61.50 \mathrm{a}$ & $3.00 \mathrm{a}$ & $4.06 \mathrm{a}$ & $5.50 \mathrm{a}$ & $6.06 \mathrm{a}$ \\
C5 & $10.85 \mathrm{a}$ & $32.05 \mathrm{a}$ & $46.33 \mathrm{~b}$ & $55.58 \mathrm{a}$ & $2.81 \mathrm{~b}$ & $3.69 \mathrm{~b}$ & $5.50 \mathrm{a}$ & $6.19 \mathrm{a}$ \\
CT & $7.29 \mathrm{a}$ & $12.54 \mathrm{~d}$ & $24.08 \mathrm{~d}$ & $24.44 \mathrm{c}$ & $2.63 \mathrm{c}$ & $3.13 \mathrm{c}$ & $3.28 \mathrm{~b}$ & $3.33 \mathrm{~b}$ \\
\hline CV & 22.6 & 10.50 & 9.37 & 12.6 & 7.08 & 10.61 & 12.36 & 10.40 \\
\hline Treatments & & Leaf area $\left(\mathrm{cm}^{2}\right)$ & & & Total plant dry weight $(\mathrm{g})$ & 60 \\
\hline & 15 & 30 & 45 & 60 & 15 & 30 & 45 & 60 \\
\hline OC & $92.35 \mathrm{a}$ & $281.69 \mathrm{a}$ & $405.66 \mathrm{~b}$ & $528.74 \mathrm{~b}$ & $0.41 \mathrm{a}$ & $2.71 \mathrm{a}$ & $5.54 \mathrm{~b}$ & $8.86 \mathrm{~b}$ \\
EH & $83.87 \mathrm{a}$ & $308.10 \mathrm{a}$ & $468.13 \mathrm{~b}$ & $522.37 \mathrm{~b}$ & $0.40 \mathrm{a}$ & $2.76 \mathrm{a}$ & $5.42 \mathrm{~b}$ & $6.84 \mathrm{c}$ \\
SMS & $70.56 \mathrm{a}$ & $118.27 \mathrm{c}$ & $485.72 \mathrm{~b}$ & $706.43 \mathrm{a}$ & $0.40 \mathrm{a}$ & $1.08 \mathrm{c}$ & $4.95 \mathrm{~b}$ & $9.74 \mathrm{~b}$ \\
C1 & $87.19 \mathrm{a}$ & $247.21 \mathrm{a}$ & $616.61 \mathrm{a}$ & $836.49 \mathrm{a}$ & $0.45 \mathrm{a}$ & $2.08 \mathrm{~b}$ & $6.93 \mathrm{a}$ & $9.18 \mathrm{~b}$ \\
C2 & $81.72 \mathrm{a}$ & $189.88 \mathrm{~b}$ & $652.68 \mathrm{a}$ & $742.56 \mathrm{a}$ & $0.44 \mathrm{a}$ & $1.96 \mathrm{~b}$ & $7.03 \mathrm{a}$ & $9.94 \mathrm{~b}$ \\
C3 & $90.29 \mathrm{a}$ & $333.73 \mathrm{a}$ & $671.82 \mathrm{a}$ & $774.00 \mathrm{a}$ & $0.48 \mathrm{a}$ & $2.64 \mathrm{a}$ & $7.24 \mathrm{a}$ & $10.93 \mathrm{a}$ \\
C4 & $101.44 \mathrm{a}$ & $336.89 \mathrm{a}$ & $612.36 \mathrm{a}$ & $696.49 \mathrm{a}$ & $0.53 \mathrm{a}$ & $3.00 \mathrm{a}$ & $7.32 \mathrm{a}$ & $9.99 \mathrm{~b}$ \\
C5 & $96.48 \mathrm{a}$ & $346.10 \mathrm{a}$ & $689.68 \mathrm{a}$ & $722.54 \mathrm{a}$ & $0.48 \mathrm{a}$ & $2.89 \mathrm{a}$ & $8.08 \mathrm{a}$ & $9.68 \mathrm{~b}$ \\
CT & $50.00 \mathrm{a}$ & $70.31 \mathrm{c}$ & $155.61 \mathrm{c}$ & $143.01 \mathrm{c}$ & $0.29 \mathrm{a}$ & $0.84 \mathrm{c}$ & $1.60 \mathrm{c}$ & $1.82 \mathrm{~d}$ \\
\hline CV & 17.84 & 19.52 & 14.82 & 11.39 & 19.77 & 16.26 & 16.94 & 7.40 \\
\hline
\end{tabular}

$\mathrm{OC}=100 \% \mathrm{OC} ; \mathrm{EM}=100 \% \mathrm{EH} ; \mathrm{SMS}=100 \% \mathrm{SMS} ; \mathrm{C} 1=75 \% \mathrm{SMS}+25 \% \mathrm{OC} ; \mathrm{C} 2=75 \% \mathrm{SMS}+25 \% \mathrm{EH} ; \mathrm{C} 3=50 \%$ $\mathrm{SMS}+50 \% \mathrm{OC} ; \mathrm{C} 4=50 \% \mathrm{SMS}+50 \% \mathrm{EH} ; \mathrm{C} 5=50 \% \mathrm{SMS}+25 \% \mathrm{OC}+25 \% \mathrm{EH} ; \mathrm{CT}=$ control with no fertilization.

The soil fertilized with SMS, single or combined with $\mathrm{OC}$ and $\mathrm{EH}$, presented greater organic matter contents (21.43), cation exchange capacity $(75.4 \%)$, and sum of exchangeable bases $(123 \%)$ than the soil without application of soil fertilizers (Table 4). These factors affect the sustainability, stability, and availability of nutrients and the soil $\mathrm{pH}$ and aeration, increasing soil fertility and agricultural production (MADEJÓN et al., 2016). Increases in organic matter contents, cation exchange capacity, and sum of exchangeable bases were also reported by Masmoudi et al. (2020), who evaluated the effects of soil fertilizer rates and OC levels on chemical and physical characteristics of different soil layers and on basil plant growth. These authors found that the application of organic fertilizer improved the soil absorption capacity for mineral elements.

Carmo et al. (2019) observed positive changes in soil chemical, physical, and biological characteristics, and different yields for basil plants grown in soil with organic compost enriched with actinobacteria. Organic fertilization promote positive effects on plant development and essential oil contents of basil plants of different varieties (BURDUCEA et al., 2018). According to Li et al. (2014), the application of OC and EH is efficient in adding stable organic matter to the soil, which is important for release of $\mathrm{N}$ to the soil and its absorption by plants. However, OC and $\mathrm{EH}$ are composted organic sources; thus, despite the slow release of nutrients to plants, the mineralization process is faster when compared to SMS, mainly for nitrogen. This explains the symptoms of $\mathrm{N}$ deficiency found in plants grown in soils with $\mathrm{OC}$ and $\mathrm{EH}$, after a few weeks. The slower availability of nutrients from SMS to plants may explain the lower SL, SD, LA, and TDW found in plants grown in soils fertilized with only SMS, when compared to those of plants grown in soils fertilized with biofertilizers formulated with SMS combined with $\mathrm{OC}$ and $\mathrm{EH}$, up to 45 days after transplanting of basil seedlings. However, the treatments with SMS and those with formulations of SMS combined with OC and $\mathrm{EH}$ presented no significant differences at 60 days after seedling transplanting, with the best results obtained with the formulation C3 (50\% SMS $+50 \%$ OC). 
Table 4. Chemical and physical characteristics of unfertilized soil, at the beginning (CT1) and end (CT2) of basil (Ocimum basilicum L.) growth, and soil fertilized with organic fertilizers based on formulations with spent mushroom substrate of Pleurotus ostreatus (SMS), organic compost (OC), and earthworm humus (EH), after basil growth for 60 days.

\begin{tabular}{|c|c|c|c|c|c|c|c|c|c|c|}
\hline \multirow{2}{*}{ Treatments } & \multirow{2}{*}{$\begin{array}{c}\mathrm{pH} \\
\mathrm{CaCl}_{2}\end{array}$} & \multirow{2}{*}{$\frac{\mathrm{OM}}{\mathrm{g} \mathrm{dm}^{3}}$} & \multirow{2}{*}{$\frac{\mathrm{P}}{\mathrm{mg} \mathrm{dm^{-3 }}}$} & $\mathrm{K}$ & $\mathrm{Ca}$ & $\mathrm{Mg}$ & $\mathrm{H}+\mathrm{Al}$ & SB & CEC & \multirow{2}{*}{$\begin{array}{c}\mathrm{BS} \\
\%\end{array}$} \\
\hline & & & & \multicolumn{6}{|c|}{ mmolc $\mathrm{dm}^{-3}$} & \\
\hline CT1 & 5.6 & 14 & 7 & $<0.9$ & 14 & 7 & 14 & 22.3 & 32.9 & 46.8 \\
\hline $\mathrm{CT} 2$ & 5.7 & 14 & 5 & $<0.9$ & 14 & 7 & 12 & 21.7 & 33.7 & 64 \\
\hline $\mathrm{OC}$ & 5.6 & 16 & 12 & 1.4 & 13 & 9 & 13 & 23.4 & 36.4 & 64 \\
\hline EH & 5.4 & 17 & 18 & 1.5 & 12 & 14 & 13 & 27.5 & 40.5 & 68 \\
\hline SMS & 6.2 & 15 & 17 & $<0.9$ & 36 & 12 & 9 & 48.6 & 57.6 & 84 \\
\hline $\mathrm{C} 1$ & 6.6 & 16 & 19 & $<0.9$ & 39 & 10 & 8 & 49.7 & 57.7 & 86 \\
\hline $\mathrm{C} 2$ & 6.5 & 16 & 18 & $<0.9$ & 30 & 10 & 9 & 40.6 & 49.6 & 82 \\
\hline $\mathrm{C} 3$ & 6.5 & 15 & 16 & 0.9 & 26 & 10 & 10 & 36.9 & 46.9 & 79 \\
\hline $\mathrm{C} 4$ & 6.3 & 15 & 17 & 0.9 & 24 & 10 & 10 & 34.9 & 44.9 & 78 \\
\hline $\mathrm{C} 5$ & 6.2 & 15 & 16 & 1.1 & 27 & 10 & 10 & 38.1 & 48.1 & 79 \\
\hline
\end{tabular}

$\mathrm{OC}=100 \% \mathrm{OC} ; \mathrm{EM}=100 \% \mathrm{EH} ; \mathrm{SMS}=100 \% \mathrm{SMS} ; \mathrm{C} 1=75 \% \mathrm{SMS}+25 \% \mathrm{OC} ; \mathrm{C} 2=75 \% \mathrm{SMS}+25 \% \mathrm{EH} ; \mathrm{C} 3=50 \%$ $\mathrm{SMS}+50 \% \mathrm{OC} ; \mathrm{C} 4=50 \% \mathrm{SMS}+50 \% \mathrm{EH} ; \mathrm{C} 5=50 \% \mathrm{SMS}+25 \% \mathrm{OC}+25 \% \mathrm{EH} ; \mathrm{CT}=$ control with no fertilizer application; $\mathrm{OM}=$ organic matter contents; $\mathrm{CEC}=$ cation exchange capacity; $\mathrm{SB}=$ sum of exchangeable bases; $\mathrm{BS}=$ base saturation. Basil plants were grown for 60 days under greenhouse conditions with irrigation by a sprinkler system, and the seedlings with $15 \mathrm{~cm}$ length were transplanted into 3.5 -liter pots containing soil fertilized with $35 \mathrm{~g}$ of organic fertilizer, according to the treatments.

The use of SMS as a soil fertilizer and its use combined with organic or mineral fertilizers have been associated with significant increases in soil mineral N (LOU et al., 2017). The use of SMS combined with chemical fertilizers changes soil characteristics, favoring the immobilization of $\mathrm{N}$ and decreasing its leaching (LOU et al., 2015). Ribas et al. (2009) evaluated SMS as a soil fertilizer for lettuce (Lactuca sativa L.) crops and found that it has a potential for soil bioremediation and that most of its nutrients are slowly mineralized by microorganisms and, consequently, slowly released to the soil. Similar results were found by Roy et al. (2015), who evaluated the potential of SMS as a biofertilizer for improvement of growth and characteristics of sweet pepper (Capsicum annuum L.) fruits.

The addition of $\mathrm{N}$ to the soil increases leaf $\mathrm{N}$ concentrations, resulting in higher photosynthetic rates (KHAN et al., 2018). Nitrogen is a key factor that regulates photosynthetic responses because it is an important component of the rubisco and other enzymes and photosynthetic structures (SUN et al., 2016; ZHONG et al., 2017). The addition of SMS to soils may also be an important source of beneficial microorganisms for plant growth, with potential to induce resistance against diseases (LOPES et al., 2015).

Thus, SMS can be a promising organic fertilizer source for agriculture, mainly for production of medicinal plants, presenting the advantages of improving soil fertility and reducing nutrient losses by leaching. The chemical composition of the organic fertilizers and the soil after their incorporation (Tables 2 and 4) assists in the understanding of the dynamics of basil plants over the crop cycle, when using treatments with organic fertilizer formulations, (Table 3) and denotes the potential of SMS for basil production.

Phosphorus is also an essential macronutrient for plant growth, but it has low mobility in the soil and is found immobilized in most soils. Phosphorus availability was found in samples of soils fertilized with SMS (Table 4). SMS can act as a soil biofertilizer, providing $\mathrm{P}$ to plants (LOU et al., 2015), and as a soil conditioner, improving the soil structure (NAKATSUKA et al., 2016). Meng et al. (2018) showed that soils fertilized with swine manure combined with SMS present higher contents of $\mathrm{N}$, P, and $\mathrm{K}$, confirming the potential of this substrate as an agricultural fertilizer.

The dry biomass distribution in the basil plant parts at the end of the experiment is presented in Figure 1. Basil leaves which represent the main commercial product of this crop, exhibit the higher essential oil contents compared to other parts of the plant, and the leaves can be consumed fresh or in processed food, and can also be used in pharmaceutical industries (TAHAMI et al., 2017). 


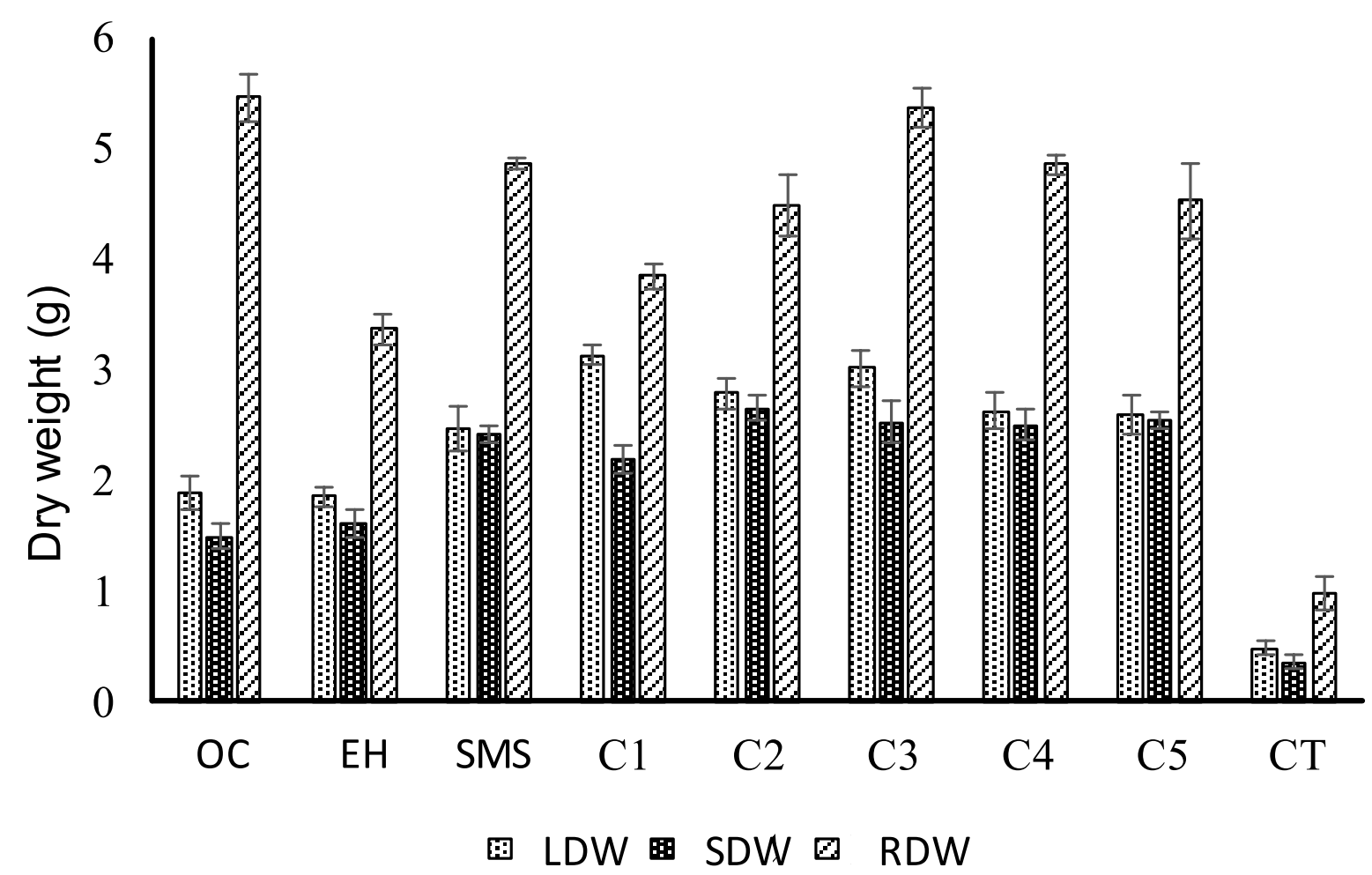
$\mathrm{OC}=100 \% \mathrm{OC} ; \mathrm{EM}=100 \% \mathrm{EH} ; \mathrm{SMS}=100 \% \mathrm{SMS} ; \mathrm{C} 1=75 \% \mathrm{SMS}+25 \% \mathrm{OC} ; \mathrm{C} 2=75 \% \mathrm{SMS}+25 \% \mathrm{EH} ; \mathrm{C} 3=50 \%$ $\mathrm{SMS}+50 \% \mathrm{OC} ; \mathrm{C} 4=50 \% \mathrm{SMS}+50 \% \mathrm{EH} ; \mathrm{C} 5=50 \% \mathrm{SMS}+25 \% \mathrm{OC}+25 \% \mathrm{EH} ; \mathrm{CT}=$ control with no fertilizer application

Figure 1. Dry biomass distribution: leaf dry weight (LDW), stem dry weight (SDW), and root dry weight (RDW) of basil (Ocimum basilicum L.) plants, at 60 days after transplanting of seedlings into 3.5-liter pots containing soil fertilized with 35 $\mathrm{g}$ of spent mushroom substrate of Pleurotus ostreatus (SMS), organic compost (OC), earthworm humus (EH), or combinations of these organic soil fertilizers.

The highest dry biomass accumulation at the end of the experiment (60 days after transplanting of seedlings) was found in the roots of basil plants. This is due to the beginning of leaf maturation, plant senescence, and increases in the root system caused by decreases in nutrient contents and photosynthesis, which increase respiration (PEIXOTO; CRUZ; PEIXOTO, 2011). The higher leaf dry weight was found in the treatments $\mathrm{C} 1(3.13 \mathrm{~g})$ and $\mathrm{C} 4(3.01 \mathrm{~g})$. These results confirm the high potential of SMS combined with OC, as found for TDW (Table 3).

Studies about dry biomass distribution in basil plants were not found. However, Ferreira et al. (2004) evaluated the growth and biomass distribution in a medicinal plant (Catharanthus roseus L.), as a function of organic soil fertilizer rates and harvest times, and found that the organic fertilizer rates affected the dry biomass accumulation in the branches, leaves, stems, and roots.

\section{Content and yield of essential oil}

The basil essential oil contents ranged from $1.24 \%$ to $1.84 \%$, with no significant differences between the treatments and the control. However, the essential oil yield was higher in plants fertilized with SMS (4.41 kg ha ${ }^{-1}$ ), and SMS combined with EH and OC, which presented essential oil yields from 3.93 to $4.97 \mathrm{~kg} \mathrm{ha}^{-1}$, with no significant differences. These yields were higher than those found in plants grown in the soil fertilized with formulations containing $100 \% \mathrm{EH}$ or $100 \%$ OC. The treatments with SMS, single or combined with $\mathrm{EH}$ and $\mathrm{OC}$, presented a significantly higher essential oil yield than the control, with yield increases that reached 324.8\% (Figure 2).

According to Bufalo et al. (2015), organic soil fertilizers can be used without compromising the basil essential oil, i.e., maintaining the basil bioactive compounds and essential oil properties, changing only the fresh and dry biomasses and nutrient accumulations in the plants. Burducea et al. (2018) found essential oil contents from $0.91 \%$ to $1.30 \%$ and relative increases in essential oil yield from $21 \%$ to $30 \%$ compared to the control, when using organic and conventional fertilizers for the growth of two cultivars of basil plants for essential oil production. 


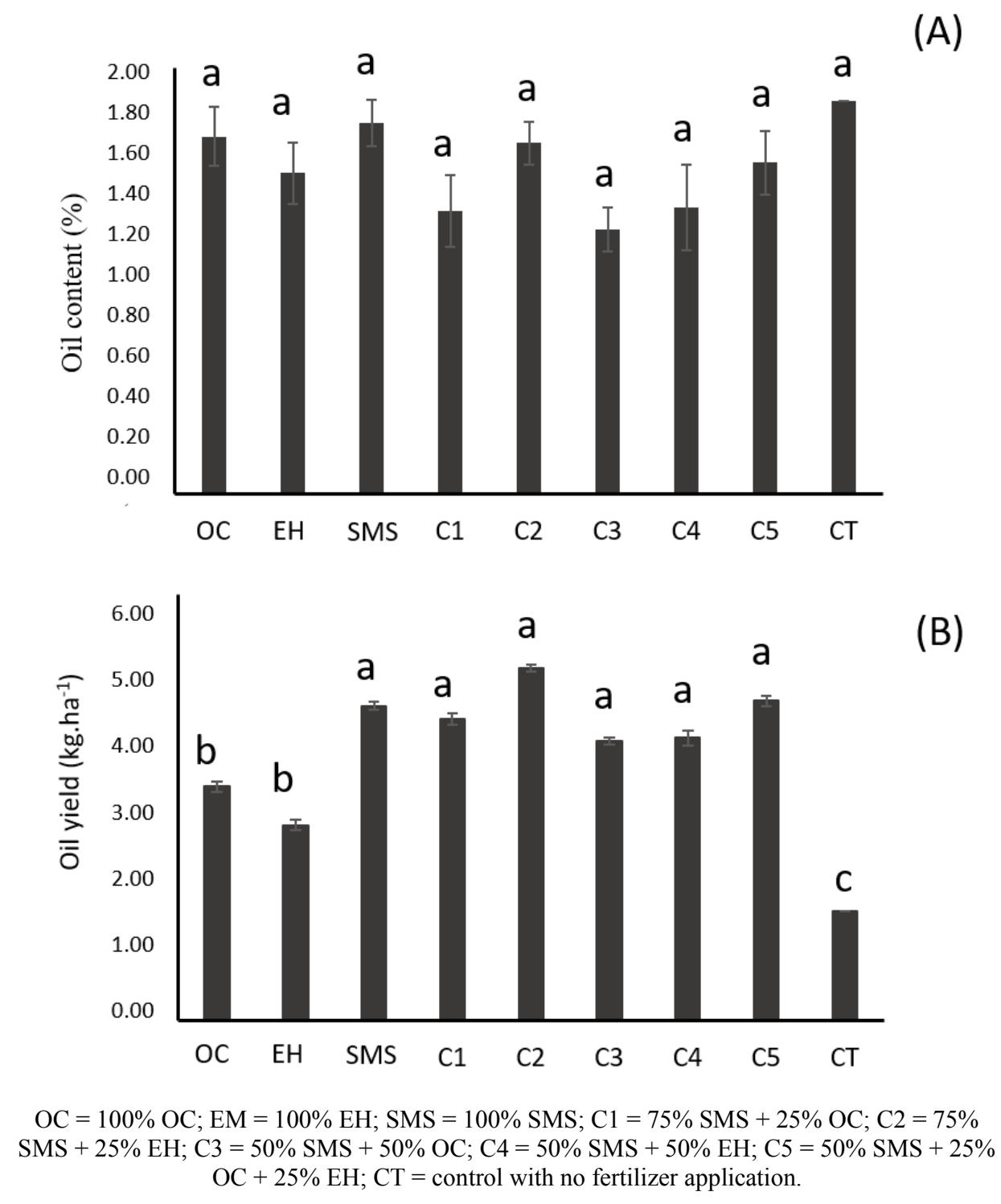

Figure 2. Essential oil content (A) and yield (B) of basil (Ocimum basilicum L.) plants grown under greenhouse conditions, in 3.5-liter pots containing soil fertilized with $35 \mathrm{~g}$ of spent mushroom substrate of Pleurotus ostreatus (SMS), organic compost (OC), earthworm humus (EH), or the combinations of these organic soil fertilizers.

Pandey, Patel and Patra (2016) evaluated the effect of different sources of nutrients, using different combinations of organic and chemical fertilizers, on biomass, yield, essential oils composition, mineral nutrition, and antioxidant activity of basil plants under field conditions and found yields from 7.12 to $13.35 \mathrm{~kg} \mathrm{ha}^{-1}$. They concluded that the organic and chemical soil fertilizers, applied single or combined, have positive effects on basil essential oil yield.

The present study confirms that SMS has potential as a soil fertilizer for basil plants and increases the biomass production (Table 3) and essential oil yield, mainly when formulated with $50 \%$ SMS and $50 \%$ OC (Table 3). According to Pandey, Patel and Patra (2016), increases in biomass of basil plants with the application of organic soil fertilizers is one of the factors that generate high essential oil yields per unit of area because of the absorption of nitrogen by basil plants.

\section{CONCLUSION}

The spent mushroom substrate of Pleurotus ostreatus has potential to be used as a soil fertilizer for growth of basil plants, with significant effect on biomass production and essential oil yield. The fertilizer formulations using spent mushroom substrate of $P$. ostreatus plus organic compost at ratios of 75:25 and 50:50 $\left(\mathrm{v} \mathrm{v}^{-1}\right)$ increase the biomass production of basil plants. The application of spent mushroom substrate of $P$. ostreatus, single or combined with organic compost and earthworm 
humus, increases the essential oil yield of basil plants.

\section{ACKNOWLEDGEMENTS}

This work was financed by CAPES (doctoral scholarship for the first author), $\mathrm{CNPq}$ (research productivity scholarship for the corresponding author; process no. 308771/2017-6), FAPESB (grants for support of graduation programs), and the Secretary of Science, Technology, and Innovation of Bahia (SECTI-UFRB agreement n. 001/2013). The financiers had no influence on the study design, data collection and analysis, publication decision, or preparation of the manuscript.

\section{REFERENCES}

ADENIPEKUN, C. O.; LAWAL, R. Uses of mushrooms in bioremediation: A review. Biotechnology and Molecular Biology Reviews, 7: 62-68, 2012.

BARH, A. et al. Mushroom crop in agricultural waste cleanup. In: BHATT, P.; SHRAMA, A. (Eds.). Microbial Biotechnology in Environmental Monitoring and Cleanup. Hershey, PA: IGI Global, 2018. v. 1, cap. 16, p. 252-266.

BUFALO, J. et al. Organic versus conventional fertilization effects on sweet basil (Ocimum basilicum L.) growth in a greenhouse system. Industrial Crops and Products, 74: 249-254, 2015.

BURDUCEA, M. et al. Fertilization modifies the essential oil and physiology of basil varieties. Industrial Crops and Products, 121: 282-293, 2018.

CARMO, C. O. et al. Bioconversion of sisal agroindustrial waste into high protein oyster mushrooms. Bioresource Technology Reports, 14: e.100657, 2021.

CARMO, C. O. et al. Utilização de compostos orgânicos inoculados com actinobactéria na adubação de manjericão (Ocimum basillicum L.). Magistra, 30: 18-27, 2019.

CARRASCO-GONZÁLEZ, J. A.; SERNASALDÍVAR, S. O.; GUTIÉRREZ-URIBE, J. A. Nutritional composition and nutraceutical properties of the Pleurotus fruiting bodies: Potential use as food ingredient. Journal of Food Composition and Analysis, 58: 69-81, 2017.

CORRÊA, R. M. et al. Adubação orgânica na produção de biomassa de plantas, teor e qualidade de óleo essencial de orégano (Origanum vulgare L.) em cultivo protegido. Revista Brasileira de Plantas Medicinais, 12: 80-89, 2010.

CORRÊA, R. C. G. et al. Biotechnological, nutritional and therapeutic uses of Pleurotus spp. (Oyster mushroom) related with its chemical composition: a review on the past decade findings. Trends in Food Science \& Technology, 50: 103117,2016

CUNHA ZIED, D. et al. Use of Spent Mushroom Substrate in New Mushroom Crops to Promote the Transition towards A Circular Economy. Agronomy, 10: 1239, 2020.

FERREIRA, D. F. Sisvar: a computer statistical analysis system. Ciência e Agrotecnologia, 35: 1039-1042, 2011.

FERREIRA, M. M. et al. Crescimento e alocação de biomassa de plantas de vinca (Catharanthus roseus (L.) G. Don) em função da adubação orgânica e época de colheita. Revista Brasileira de Plantas Medicinais, 6: 72-6, 2004

GARCÍA-DELGADO, C. et al. Cadmium and lead bioavailability and their effects on polycyclic aromatic hydrocarbons biodegradation by spent mushroom substrate. Environmental Science and Pollution Research, 20: 8690-8699, 2013.

GIRMAY, Z. et al. Growth and yield performance of Pleurotus ostreatus (Jacq. Fr.) Kumm (oyster mushroom) on different substrates. Amb Express, 6: $1-7,2016$.

HACKETT, R. Spent mushroom compost as a nitrogen source for spring barley. Nutrient Cycling in Agroecosystems, 102: 253-263, 2015.

HANAFI, F. H. M. et al. Environmentally sustainable applications of agro-based spent mushroom substrate (SMS): an overview. Journal of Material Cycles and Waste Management, 20: 1383-1396, 2018.

HOLBECK, B. et al. Recoveries of $15 \mathrm{~N}$-labelled fertilizers (chicken manure, mushroom compost and potassium nitrate) in arable topsoil after autumn application to winter cover crops. Soil and Tillage Research, 130: 120-127, 2013.

KAPU, N. U. S. et al. Surfactant-assisted pretreatment and enzymatic hydrolysis of spent mushroom compost for the production of sugars. Bioresource Technology, 114: 399-405, 2012.

KHAN, S. et al. Alteration in yield and oil quality 
traits of winter rapeseed by lodging at different planting density and nitrogen rates. Scientific Reports, 8: 1-12, 2018.

KOUTROTSIOS, G. et al. Bioactive compounds and antioxidant activity exhibit high intraspecific variability in Pleurotus ostreatus mushrooms and correlate well with cultivation performance parameters. World Journal of Microbiology and Biotechnology, 33: 1-14, 2017.

LAMEIRA, O. A.; PINTO, J. E. B. P. Plantas medicinais: do cultivo, manipulação e uso à recomendação popular. 1. ed. Belém, PA: Embrapa Amazônia Oriental, 2008. 264 p.

LI, S. et al. Soil organic nitrogen and its contribution to crop production. Journal of Integrative Agriculture, 13: 2061-2080, 2014.

LIMA, J. C. et al. Macronutrient fertilizers on basil growth and yield. Comunicata Scientiae, 11: e3200, 2020.

LOPES, R. X. et al. Application of spent Agaricus subrufescens compost in integrated production of seedlings and plants of tomato. International Journal of Recycling Organic Waste in Agriculture, 4: 211-218, 2015.

LOU, Z. et al. Release characteristics and control of nitrogen, phosphate, organic matter from spent mushroom compost amended soil in a column experiment. Process Safety and Environmental Protection, 98: 417-423, 2015.

LOU, Z. et al. Composition variability of spent mushroom substrates during continuous cultivation, composting process, and their effects on mineral nitrogen transformation in soil. Geoderma, 307: 30$37,2017$.

MADEJÓN, P. et al. Three-year study of fastgrowing trees in degraded soils amended with composts: Effects on soil fertility and productivity. Journal of Environmental Management, 169: 1826,2016

MARQUES, E. L. S. et al. Spent mushroom compost as a substrate for the production of lettuce seedlings. Journal of Agricultural Science, 6: 138-143, 2014.

MARTIN, T. N. et al. Uso do software ImageJ na estimativa de área foliar para a cultura do feijão. Interciencia, 38: 843-848, 2013.

MASMOUDI, S. et al. Effects of compost and manure application rate on the soil physico-chemical layers properties and plant productivity. Waste and
Biomass Valorization, 11: 1883-1894, 2020.

MENG, X. et al. Effect of pig manure on the chemical composition and microbial diversity during co-composting with spent mushroom substrate and rice husks. Bioresource Technology, 251: 22-30, 2018.

NAKATSUKA, H. et al. Effects of fresh spent mushroom substrate of Pleurotus ostreatus on soil micromorphology in Brazil. Geoderma, 269: 54-60, 2016.

NARDI, S. et al. Soil organic matter properties after 40 years of different use of organic and mineral fertilizers. European Journal of Agronomy, 21: 357-367, 2004

NASCIMENTO FILHO, W. B.; FRANCO, C. R. Avaliação do potencial dos resíduos produzidos através do processamento agroindustrial no Brasil. Revista Virtual de Química, 7: 1968-1987, 2015.

NUNES, M. D. et al. Nitrogen supplementation on the productivity and the chemical composition of oyster mushroom. Journal of Food Research, 1: 113-119, 2012.

PANDEY, V.; PATEL, A.; PATRA, D. D. Integrated nutrient regimes ameliorate crop productivity, nutritive value, antioxidant activity and volatiles in basil (Ocimum basilicum L.). Industrial Crops and Products, 87: 124-131, 2016.

PAREDES, C. et al. Effects of spent mushroom substrates and inorganic fertilizer on the characteristics of a calcareous clayey-loam soil and lettuce production. Soil Use and Management, 32: 487-494, 2016.

PAULA, F. S. et al. Stabilization of spent mushroom substrate for application as a plant growth-promoting organic amendment. Journal of Environmental Management, 196: 476-486, 2017.

PEIXOTO, C. P.; CRUZ, T. V.; PEIXOTO, M. F. S. Análise quantitativa do crescimento de plantas: conceitos e prática. Enciclopédia biosfera, 7: 51-76, 2011

RAMAN, J. et al. Cultivation and Nutritional Value of Prominent Pleurotus Spp.: An Overview. Mycobiology, 49: 1-14, 2020.

RIBAS, L. C. C. et al. Use of spent mushroom substrates from Agaricus subrufescens (syn. A. blazei, A. brasiliensis) and Lentinula edodes productions in the enrichment of a soil-based potting media for lettuce (Lactuca sativa) cultivation: 
growth promotion and soil bioremediation. Bioresource Technology, 100: 4750-4757, 2009.

ROY, S. et al. Evaluation of spent mushroom substrate as biofertilizer for growth improvement of Capsicum annuum L. Journal of Applied Biology and Biotechnology, 3: 22-27, 2015.

SARDAR, H. et al. impact of various agro-industrial wastes on yield and quality of Pleurotus sajor-caju. Pakistan Journal of Phytopathology, 28: 87-92, 2016.

SHARMA, R. K.; ARORA, D. S. Fungal degradation of lignocellulosic residues: an aspect of improved nutritive quality. Critical Reviews in Microbiology, 41: 52-60, 2015.

SILVA, R. M. et al. Biological efficiency and nutritional value of Pleurotus ostreatus cultivated in agro-industrial wastes of palm oil fruits and cocoa almonds. Arquivos do Instituto Biológico, v. 87, 2020.

SUN, J. et al. Nitrogen can improve the rapid response of photosynthesis to changing irradiance in rice (Oryza sativa L.) plants. Scientific Reports, 6: 1 $-10,2016$.

TAHAMI, M. K. et al. Plant growth promoting rhizobacteria in an ecological cropping system: A study on basil (Ocimum basilicum L.) essential oil production. Industrial Crops and Products, 107: 97-104, 2017.

VIEIRA, F. R.; ANDRADE, M. C. N. Optimization of substrate preparation for oyster mushroom (Pleurotus ostreatus) cultivation by studying different raw materials and substrate preparation conditions (composting: phases I and II). World Journal of Microbiology and Biotechnology, 32: 1 $-9,2016$.

WANNISSORN, B. et al. Antibacterial properties of essential oils from Thai medicinal plants. Fitoterapia, 76: 233-236, 2005.

WANZENBÖCK, E. et al. Wheat bran biodegradation by edible Pleurotus fungi-A sustainable perspective for food and feed. LWTFood Science and Technology, 86: 123-131, 2017.

ZHONG, C. et al. Nitrogen metabolism in adaptation of photosynthesis to water stress in rice grown under different nitrogen levels. Frontiers in Plant Science, 8: e1079, 2017. 